\title{
أخلاق الدعاة في ضوء الكتاب والسنة
}

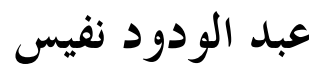

الدكتور عبد الودود نفيس مدرس بالجامعة الاسلاميللحكومية جمبر لئر

\section{ملخص البحث}

إن الدعوة الي الله أصل عظيم من أصول الإسلام. وهي من أسباب النصر على ملى

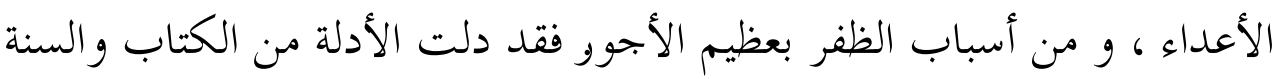

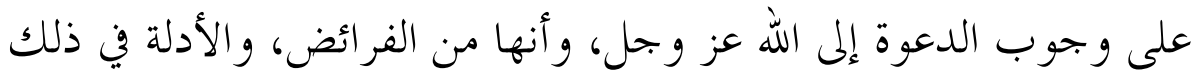

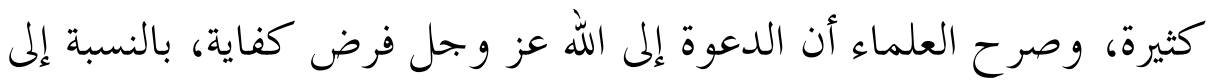

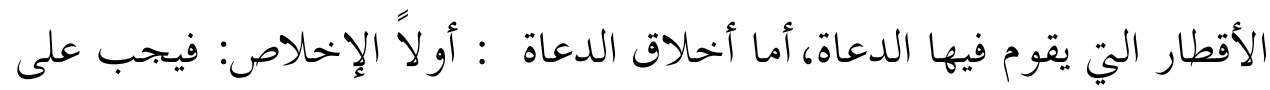

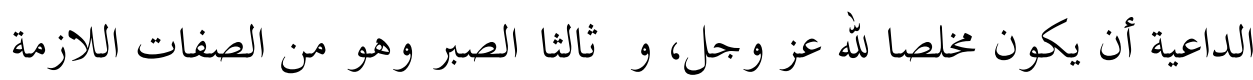

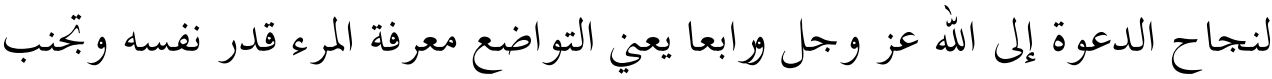
الكبر ، ويتطلب أن يتجنب الإنسان المباهاة .ما فيه من الفضائل والمفاخرة بالجاه

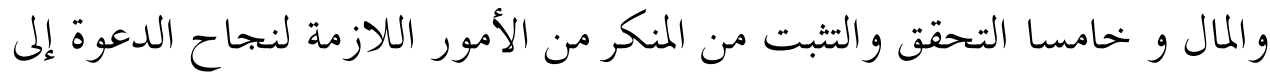
الله عز وجل ، التحقق والتثبت من المنكر المطلوب إزالته وتغييره و و سادسا:

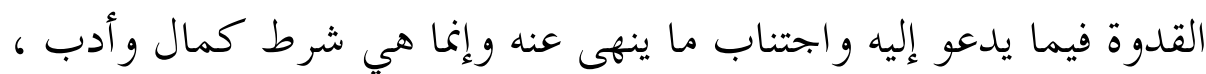

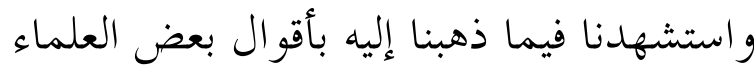

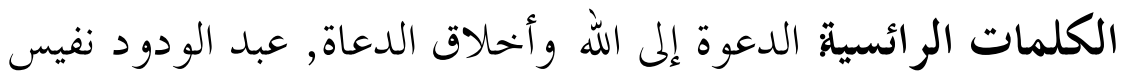

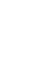

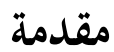

إن الدعوة الي الله أصل عظيم من أصول الإسلام ، ولا شك أن صلاح العباد في 
معاشهم ومعادهم متوقف على طاعة الله عز وجل وطاعة رسوله صلى الله عليه وسلم ، وتمام الطاعة متوقف على الأمر بالمعروف و النهي عن المنكر، وبه كانت هذه الأمة خير

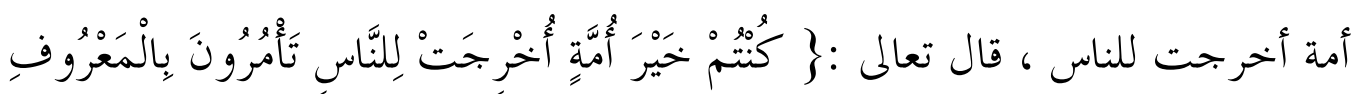

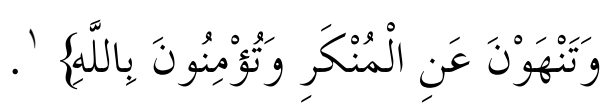

وقد أولى القر آن الكريم والسنة النبوية هذا الأمر أهمية بالغة ، ففيه تحقيق الولاية

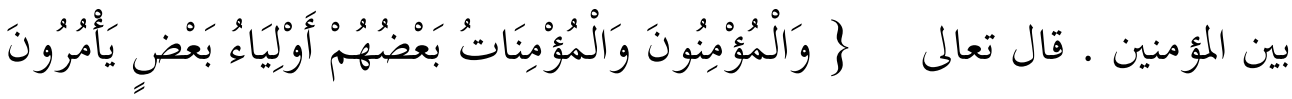

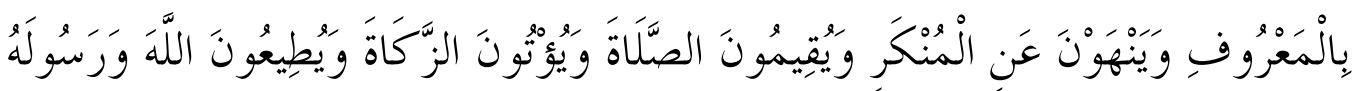

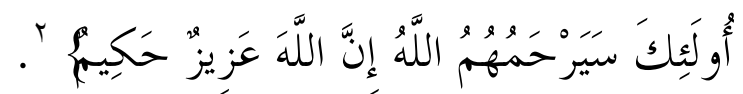

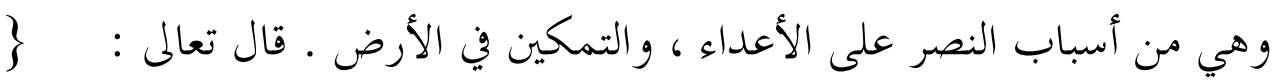

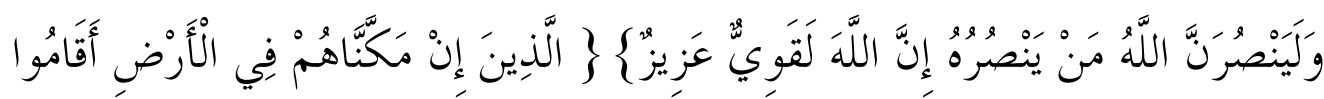

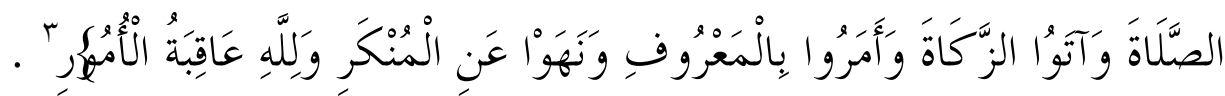
وفيه الأمن من الهلاكك ، والمحافظة على صلاح المجتمعات ، فعن النعمان بن بشير رضي الله عنه قال : قال الني صلى الله عليه وسلم : 》ا مثل القائم على حدود الله

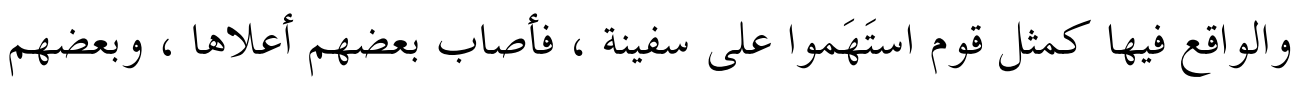
أسفلها ، فكان الذين في أسفلها إذا استقوا من الماء مروا على من فوقهم ، فقالو الو أنا

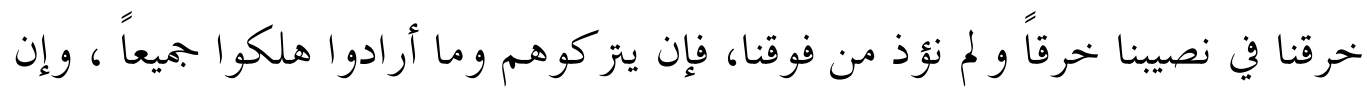

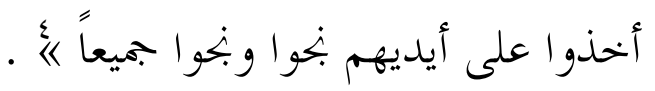

$$
\begin{aligned}
& 1 \text { سورة آل عمران ، الآية } 110 \\
& \text { سورة التوبة ، الآية } 71 \\
& \text { سمورة الحج ، الآيتان 40-41 سلية } \\
& \text { 4 صحيح البخاري مع الفتح ، } 5 \text { / 132 لهورة لانتان }
\end{aligned}
$$


و الدعوة الي اللهمن أسباب الظفر بعظيم الأجور، وتكثير الحسنات، قال تعالى :

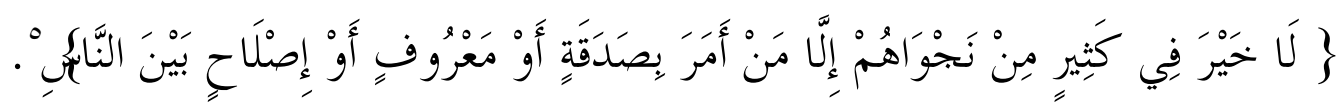

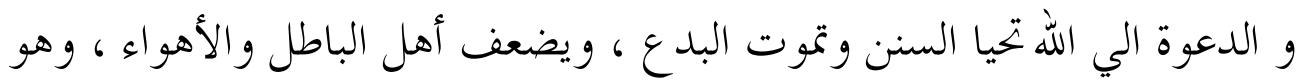
من أبرز صفات المؤمنين وسماتهم ، ومن أعظم الوسائل لقوتهم وتماسكهم، و الغفلة عنه وله

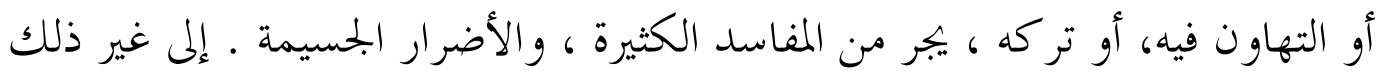
من الفو ائد و الثمرات الكثيرة المتزتبة على الأمر بالمعروف والنهي عن المنكر .

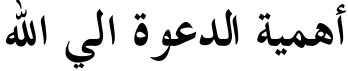

الدعوة الي الله هي الجهاد الدائم المفروض على المسلم ، وهو أصل مهم من أصول قيام حضارة الإسلام لا قيام لشريعة الإسلام بدونه " وهو القطب الأعظم في الدين ، وهو المهم الذي ابتعث الله له النبيين أجمعين ولو طوي بساطه وأهمل علمه وعمله لتعطلت النبوة واضمحلت الديانة وعمت الفترة وفشت الضلالة وشاعت الجهالة واستشرى الفساد واتسع الخرق وخربت البلاد ، وهلك العباد ، و لم يشعروا بالهلاك إلا

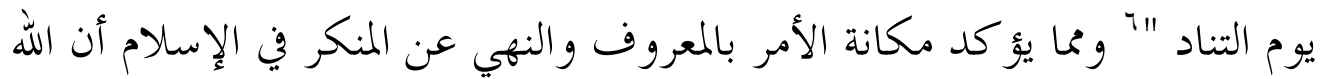
تعالى قد ذكر من أوصاف الصالحين أنهم يأمرون بالمعروف وينهون عن المنكر ، قال

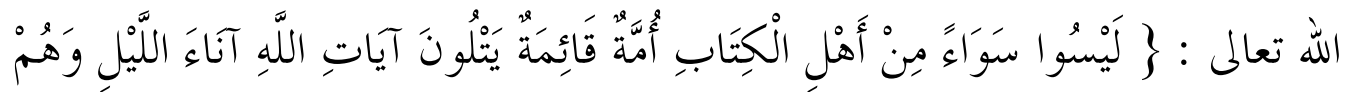

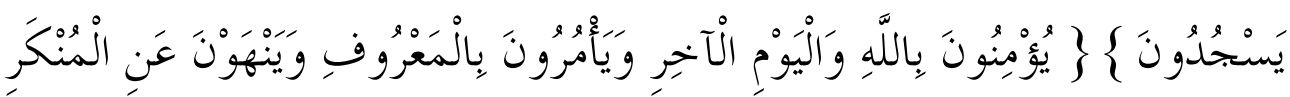

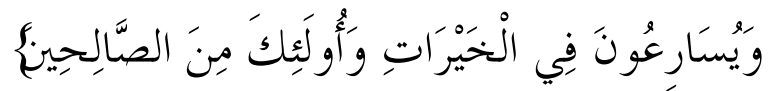

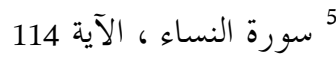

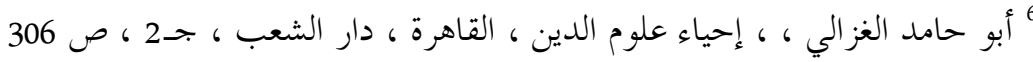

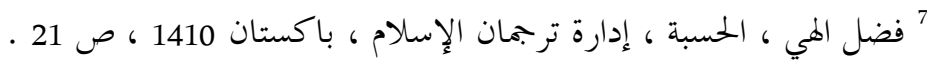


وقد وصف الله تعالى الأمة الإسلامية بأنها خير أمة أخرجت للناس ؛ لأنها تأمر

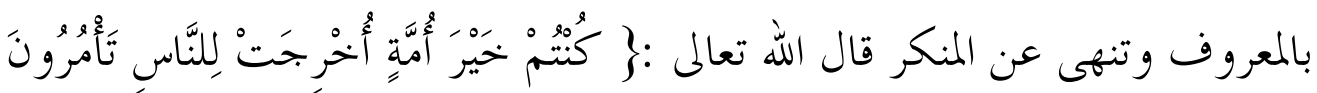

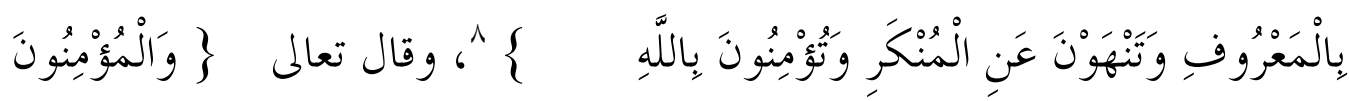

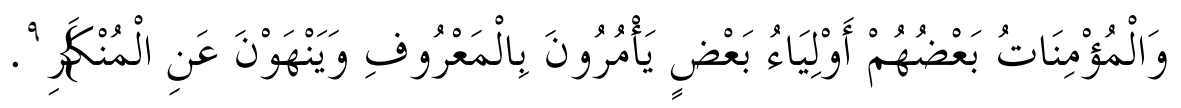
ولهذا قال أبو هريرة - رضي الله عنه - : " كنتم خير الناس للناس تأتون بهم في القيود بهرد و السلاسل حتى تدخلوهم الجنة . فبين الله سبحانه أن هذه الأمة خير الأمم للناس ، فهم أنفعهم لهم ، وأعظمهم إحسانا إليهم ؛ لأنهم كملو ا كل خير ونفع للناس بأمرهم بالمعروف ونهيهم عن المنكر من جهة الصفة والقدر ، حيث أمروا بكل معروف ونهوا عن كل منكر لكل أحد لها. و ومما يدل على أهمية للدعوة الي الله

قول حذيفة - رضي الله عنه - : " الإسلام ثمانية أسهم " وذكر منها الأمر بالمعروف سهم ، والنهي عن المنكر سهم ، وقد خاب من لا سهم تهّه .

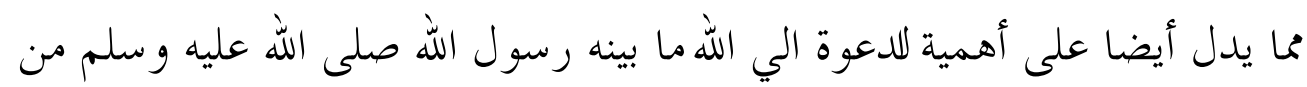
أن الأمر بالمعروف و النهي عن المنكر صدقة يؤجر المرءعلى قيامه بها ـ فقد روى الإمام مسلم عن أبي ذر - رضي الله عنه - 》ا أن أناسا من أصحاب النبي صلى الله عليه

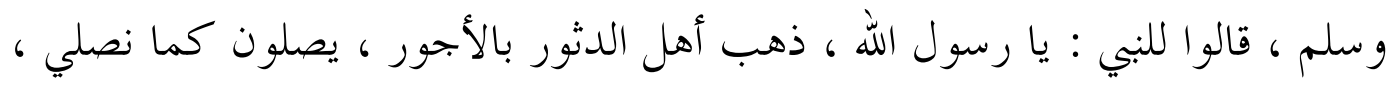

$$
\text { 9 سورة آل عمران ، الآية } 110
$$

10 ${ }^{10}$ ابن تيمية الأمر بالمعروف ، الابة والنهي عن المنكر ، تعقيق عممد السيد الجليند ، جدة ، دار الجتمع ، الطبعة

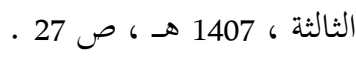
12511 
و يصومون كما نصوم ، ويتصدقون بفضول أمواهم ، قال : أوليس قد جعل الله لكم ما تصدقون به ؟ أن بكل تسبيحة صدقة ، و كل تكبيرة صدقة ، و كل تحميدة صدقة ، و كل تهليلة صدقة ، وأمر بالمعروف صدقة ونهي عن المنكر صدقة 《ه.

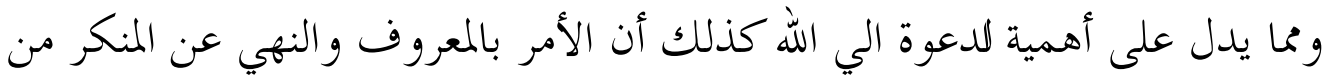

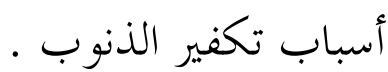
قال رسول الله صلى الله عليه وسلم : 》ا فتنة الرجل في أهله وماله وجاره تكفرها

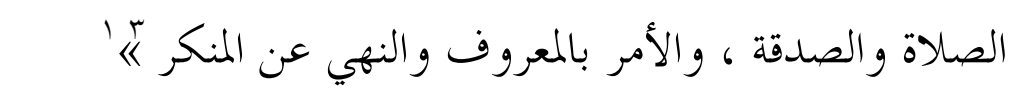

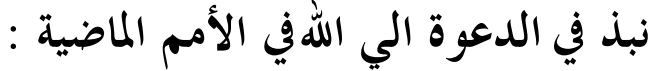

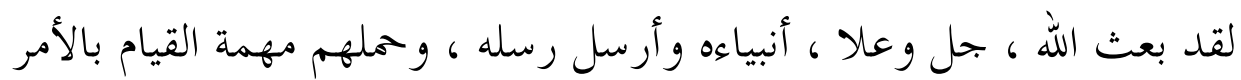

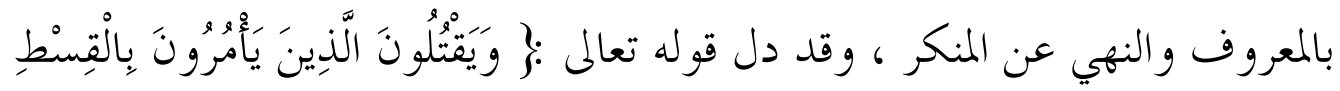

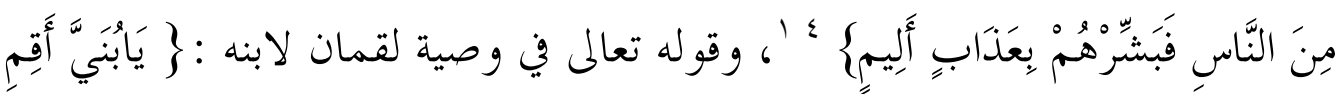

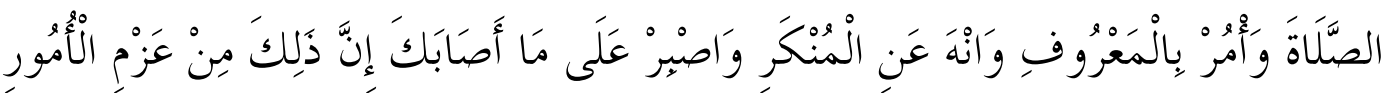
ج، دلت هذه الآيات الكريمة على أن الأمر بالمعروف و النهي عن المنكر كانا واجبين في

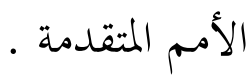

ويقول ابن تيمية - رحمه الله - : " الأمر بالمعروف و النهي عن المنكر الذي أنزل

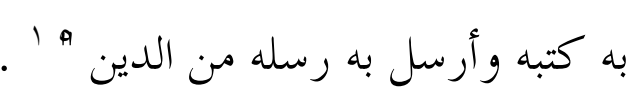

$$
\begin{aligned}
& \text { 12 }{ }^{12} \\
& \text { ل } \\
& 14
\end{aligned}
$$

15 بابن تيمية الحسبة في الإسلام ( ضمن بمموعة الرسائل ) ، القاهرة ، المطبعة الحسينية 132 هـ ، ص 36 ـ 
ويقول الرازي : " الأمر بالمعروف والنهي عن المنكر والإيمان بالله ، إن هذه

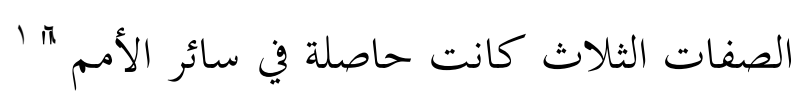

يقول القرطبي : " إن الأمر بالمعروف والنهي عن المنكر كانا واجبين في الأمم

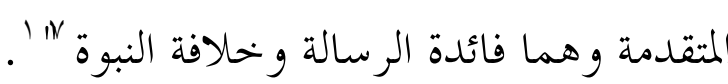

ويقول العلامة سيف الدين الآمدي : " ما من أمة إلا وقد أمرت بالمعروف ونهت

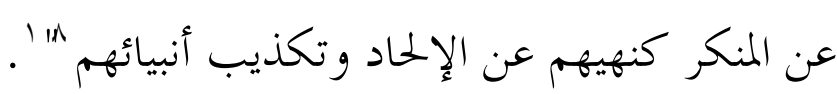

وعندما بعث نبينا صلى الله عليه وسلم برسالة الإسلام للناس كافة ، قام بواجب

الأمر بالمعروف بنفسه و كلف بعض أصحابه بالقيام به ، وقد وصف الله ، جل وعلا ،

نبيه محمد صلى الله عليه وسلم بأنه يقوم بالأمر بالمعروف و النهي عن المنكر وذلك في

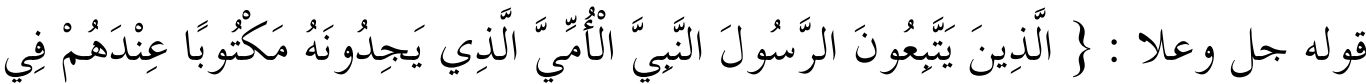

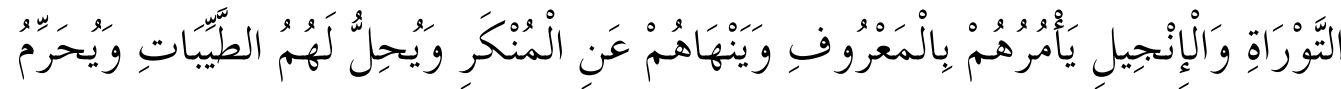

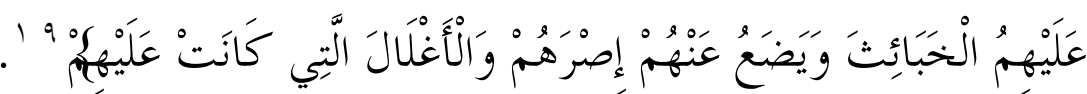
كان صلى الله عليه وسلم كما وصفه ربه تعالى آمرا بالمعروف إذا رآه مترو كا ، ناهيا عن المنكر إذا و جده مفعو لا ـ و لم يقتصر احتسابه على جانب من جوانب الحياة بل شمل جميع شئون الحياة كلها ومن أمثلة قيامه بالأمر بالمعروف والنهي عن المنكر بنفسه وإسناده إلى غيره 3) ما رواه في الإمام أحمد من حديث عبد الله بن عمر ، رضي الله عنهما ، قال : إ أمرني رسول الله أن آتيه بمدية - وهي الشفرة - فأتيته بها

16 الرازي ، التفسير الكبير ، طهران ، دار الكتب العلمية ، 3 : 27

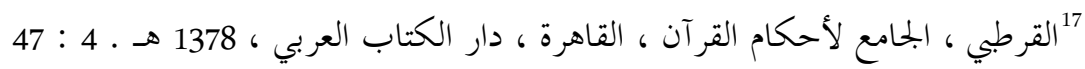

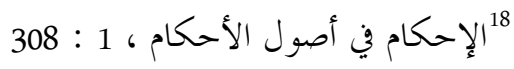
19 
فأرسل بها ، فأرهفت ، ثم أعطانيها ، وقال " اغذ علي بها " فقعلت ، فخرج بأصحابه إلى أسواق المدينة ، و فيها زقاق خمر قد جلبت من الشام ، فأحذ المدية مين ، فشق ما كان من تلك الزقاق بكضرته ، ثم أعطانيها وأمر أصحابه الذين كانوا معه أن يمضوا معي ، وأن يعاونوني ، وأمرني أن آتي إلى الأسواق كلها فلا أجد زق خمر إلا شققته ، فقعلت فلم أترك في أسو اقها زقا إلا شققته 《ه وبعد وفاة الرسول صلى الله عليه وسلم ، قام خلفاؤه وأصحابه بواجب الأمر بالمعروف والنهي عن المنكر خير قيام ، وامتد اهتمام المسلمين بواجب الأمر بالمعروف و النهي عن المنكر قرونا طويلة ، و كان من نتائج القيام بهذا الواجب العظيم أن عاث المحتمع الإسالامي في أنظف حياة وأسعدها وآمنها ، لا يكاد يقع فيه منكر حتى يتتابع الإنكار له ، و يتداعى المسلمون إليه فيقضى عليه في مهلده ، و بهذا عاش بحتمعا مهيبا ، طاهرا ، لا يتوقح فيه أهل الفساد ، و لا يتجرأ فيه أهل المعصية ، و كانت العزة فيه للّ له ولرسوله وللمؤمنين الآمرين بالمعروف و الناهين عن المنكر ، و الحافظين لحدود الله ، حتى خلفت بعد ذلك خلوف ، جعلوا الدنيا أكبر همهم ، ومبلغ علمهم ، و ونسوا الله فأنساهم أنفسهم ، فتقطع بينهم ، وانفرط عقدهم ، فلم يأمرو ا.معروف و لم ينهوا عن منكر ، إلا قليل ممن رحم ربك فكان ذلك سبب ما أصابهم من ذل واستعمار وفقر

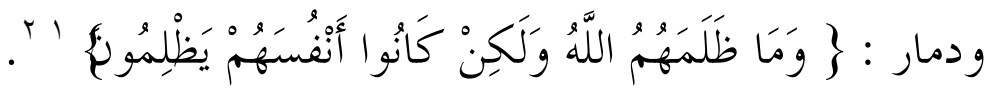
قد كان الأمر بالمعروف والنهي عن المنكر ، و التواصي بهما ، والصبر عليهما السر فيما تحقق للمسلمين من خير وبر وحياة نظيفة ودنيا صالحة واسعة على مدى تاريخهم 
الطويل

\section{حكم الدعوة إلى الله عز وجل}

أما حكمها : فقد دلت الأدلة من الكتاب والسنة على وجوب الدعوة الدوة إلى الله عز

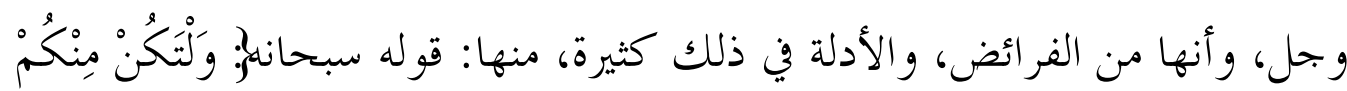

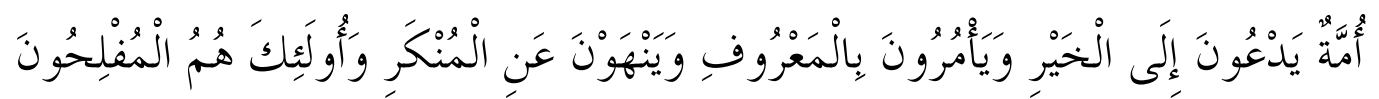
\{

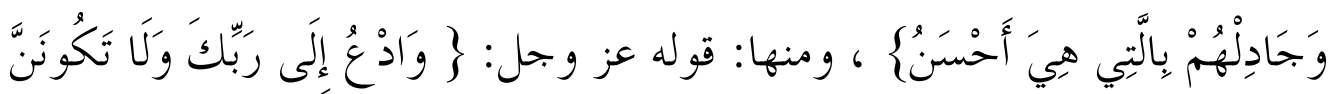

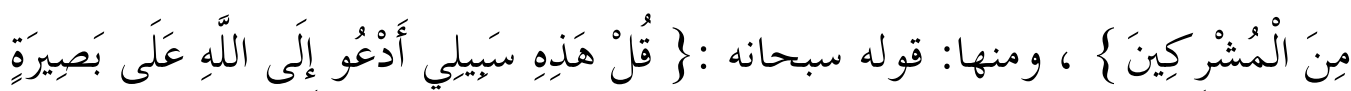
أَنَا وَمَنِ انَبَعَنِين

وصرح العلماء أن الدعوة إلى الله عز وجل فرض كفاية ها، بالنسبة إلى الأقطار التي يقوم فيها الدعاة، فإن كل قطر وكل إقليم يمتاج إلى الدعوة وإلى النشاط فيها، فهي فرض كفاية إذا قام بها من يكفي سقط عن الباقين ذلك الواجب، وصارت الدعوة في حق الباقين سنة مؤكدة، وعملا صالحا جليلا.

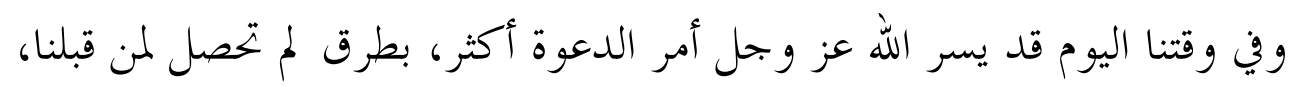
فأمور الدعوة اليوم متيسرة أكثر، من طرق كثيرة، وإقامة الحجة على الناس اليوم ممكنة

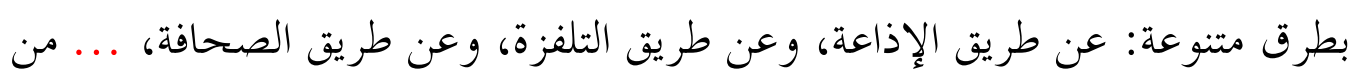
طرق شتى.

22

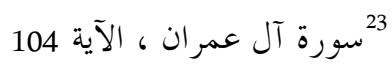
24 القرطبي ، الجامع لأحكام القر آن ، القاهرة ، دار الكتاب العربي ، 1378 هـ ، ، جـ 4 ، ص 165 . 
أما كيفية الدعوة وأسلو بها : فقد بينها الله عز وجل في كتابه الكريم، وفيما جاء لاء

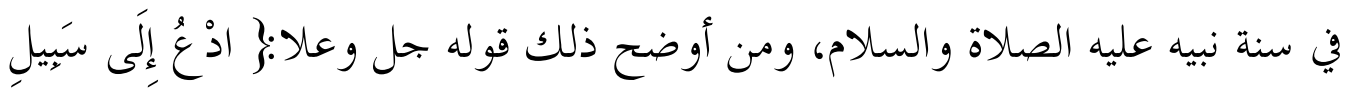

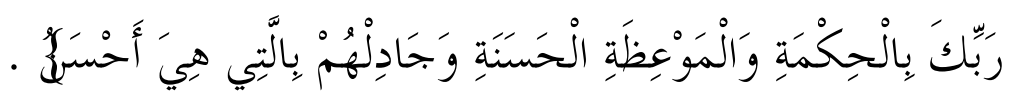

فأوضح سبحانه الكيفية التي ينبغي أن يتصف بها الداعية ويسلكها، يبدأ أولا

بالحكمة، والمراد بها: الأدلة المقنعة الواضحة الكاشفة للحق، والداحضة للباطل؛ ولهذا قال بعض المفسرين: المعنى: بالقرآن؛ لأنه الحكمة العظيمة؛ لأن فيه البيان والإيضاح للحق بأكمل وجه، وقال بعضهم: معناه: بالأدلة من الكتاب والسنة. وبكل حال، فالحكمة كلمة عظيمة، معناها: الدعوة إلى الله بالعلم و البصيرة، والأدلة الو اضحة المقنعة الكاشفة للحق، والمبينة له، وهي كلمة مشتز كة تطلق على معان كثيرة، تطلق على النبوة، وعلى العلم والفقه في الدين، وعلى العقل، وعلى الورع،

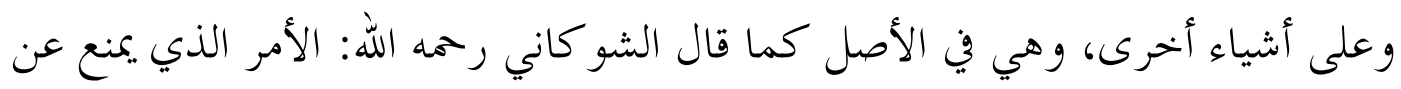
السفه، هذه هي الحكمة، والمعنى: أن كل كلمة و كل مقالة تردعك عن السفه، وتزجرك عن الباطل فهي حكمة، وهكذا كل مقال واضح صريح، صحيح في نفسه، فهو حكمة، فالآيات القرآنية أولى بأن تسمى حكمة، وهكذا السنة الصحيحة أولى بأن تسمى حكمة بعد كتاب الله، وقد سماها الله حكمة في كتابه العظيم، كما في قوله جل

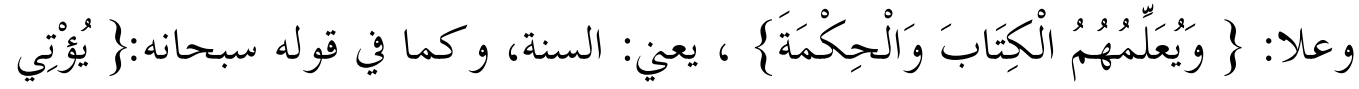

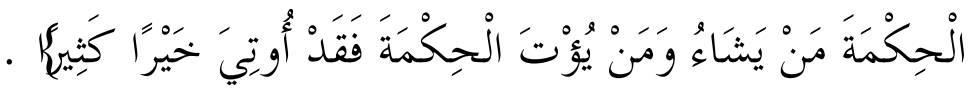
فالأدلة الو اضحة تسمى: حكمة، والكلام الواضح المصيب للحق يسمى: حكمة، كما تقدم، ومن ذلك الحكمة التي تكون في فم الفرس: وهي بفتح الحاءو والكاف، سميت بذلك؛ لأنها تمنع الفرس من المضي في السير، إذا جذبها صاحبها بهذه الحكمة. 
الحممة كلمة تمنع من سمعها من المضي في الباطل، وتدعوه إلى الأخذ بالحق والتأثر به، والوقوف عند الحد الذي حده الله عز وجل.

فعلى الداعية إلى الله عز وجل أن يدعو بالحكمة، ويبدأ بها، ويعنى بها، فإذا كان المدعو عنده بعض الجفا والاعتزاض دعوته بالموعظة الحسنة، بالآيات والأحاديث التي فيها الوعظ والتزغيب، فإن كان عنده شبهة جادلته بالتي هي أحسن، ولا تغلظ عليه، بل تصبر عليه ولا تعجل ولا تعنف، بل بتحهد في كشف الشبهة، وإيضاح الأدلة بالأسلوب الحسن، هكذا ينبغي لك أيها الداعية أن تتحمل وتصبر ولا تشدد؛ لأن هذا أقرب إلى الانتفاع بالحق وقبوله وتأثر المدعو، وصبره على البحادلة والمناقشة، وقد أمر الله جل وعلا موسى وهارون لما بعثهما إلى فرعون أن يقولا له قو لا لينا وهو أطغى الطغاة،

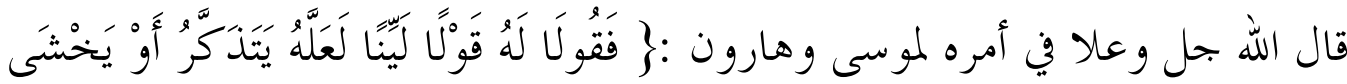

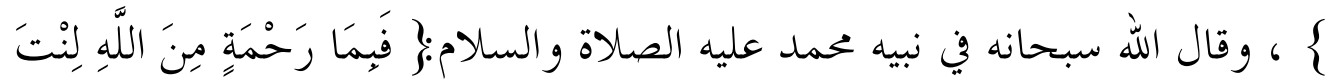

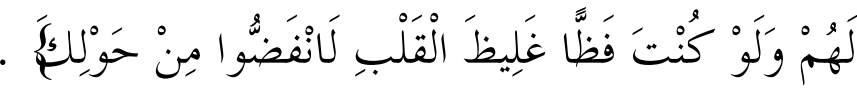

فعلم بذلك أن الأسلوب الحكيم والطريق المستقيم في الدعوة أن يكون الداعي حكيما في الدعوة، بصرا بأسلو بها، لا يعجل ولا يعنف، بل يدعو بالحكمة، وهي المقال

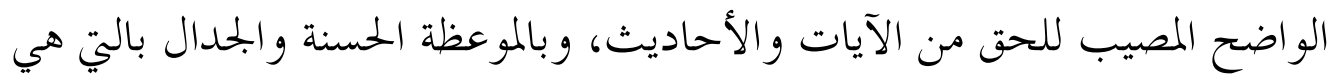
أحسن، هذا هو الأسلوب الذي ينبغي لك في الدعوة إلى الله عز وجل، أما الدعوة بالجهل فهذا يضر ولا ينفع، كما يأتي بيان ذلك إن شاء الله عند ذكر أخلاق الدعاة؛ لأن الدعوة مع الجهل بالأدلة قول على الله بغير علم، وهكذا الدعوة بالعنف والشدة ضر رها أكثر. 


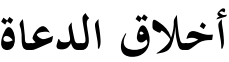

أما أخلاق الدعاة التي ينبغي أن يكونو اعليها، فقد أوضحها الله جل وعلا في آيات كثيرة، في أماكن متعددة من كتابه الكريم منها:

أولاً: الإخحلاص:

فيجب على الداعية أن يكون مخلصا لله عز وجل، لا يريد رياء ولا سمعة، ولا ثناء

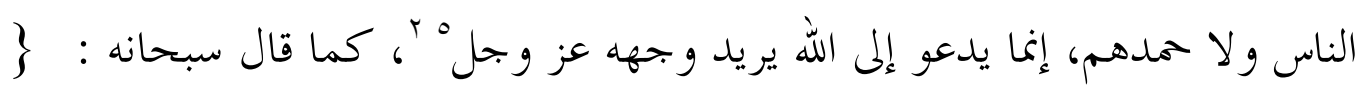

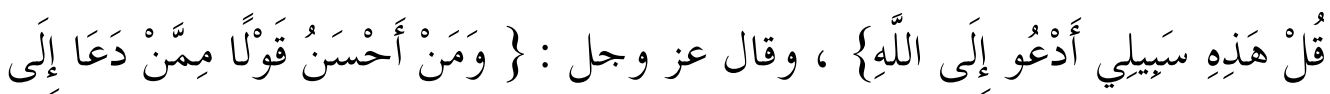
اللَّهِ \{

فعليك أن تخلص لله عز وجل، هذا أهم الأخلاق، هذا أعظم الصفات أن تكون في دعوتك تريد وجه الله والدار الآخرة.

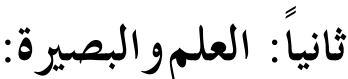

أن يكون الداعية على بينة في دعوته - أي: على علم - لا تكن جاهلا بما تدعو

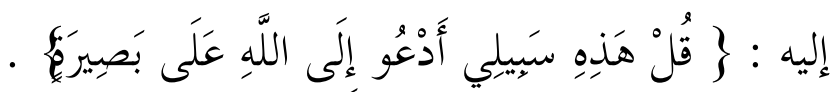

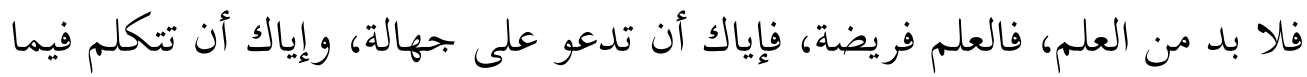
لا تعلم، فالجاهل يهدم ولا يبني، ويفسد ولا يصلح، فاتق الله يا عبد الله، إياك أن تقوله

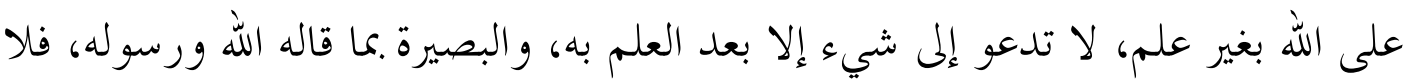
بد من بصيرة وهي العلم، فعلى طالب العلم وعلى الداعية أن يتبصر فيما يدعو إليه، 25 ممد محمود الصواف ، الدعوة والدعاة ، القاهرة ، دار الاعتصام ، ص 36 - 37 
وأن ينظر فيما يدعو إليه ودليله، فإن ظهر له الحق وعرفه دعا إلى ذلك، سواء كان ذلك فعلا أو تركا، فيدعو إلى الفعل إذا كان طاعة لله ورسوله، ويدعو إلى ترك ما نهى الله عنه ورسوله على بينة وبصيرة.

\section{ثالثا : الصبر :}

الصبر من الصفات اللازمة لنجاح الدعوة إلى الله عز وجل ، وهو فضيلة من

الفضائل التي حث عليها القرآن الكريم في أكثر من آية حتى وردت مادة ( ص ـ ب . ر ) في القرآن الكريم في مائة وثلاثة مواضع ·

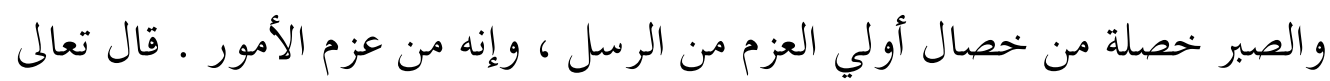

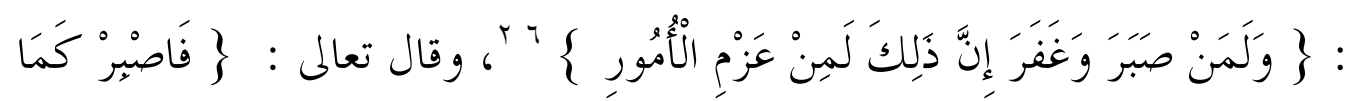

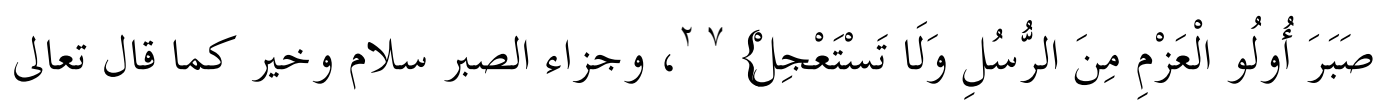

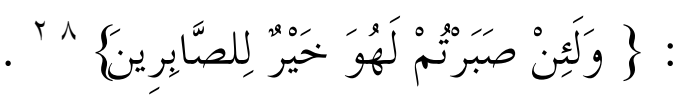

وقد أوضح العلماء - رمهم الله - أهمية الصبر بالنسبة للآمر بالمعروف والناهي عن المنكر ، يقول الإمام الرازي : " من يأمر بالمعروف وينهى عن المنكر يؤذى فأمره

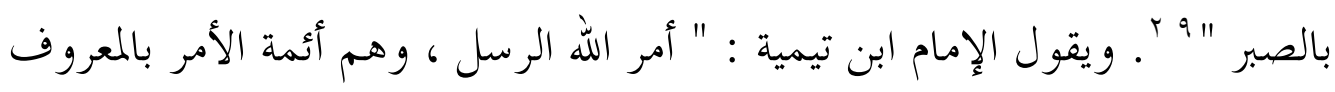

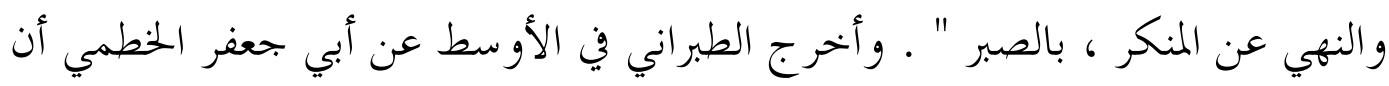
جده عمير بن حبيب بن حماسة ، رضي الله عنه ، و كان قد أدرك البي صلى الله عليه 26 - مسورة الشورى ، الآية 43

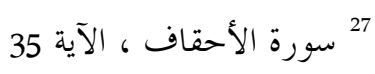
126 مورة النحل ، الآية 128 29 ابن تيمية ، الحسبة في الإسلامية ، القاهرة ، المطبعة الحسينية . 
و سلم عند احتلامه أوصى لولده ، فقال : " يا بني إياك وبحالسة السفهاء فإن بحالستهم داء ، ومن يحلم عن السفيه يسر . . . . ومن يحبه يندم . . . . وإذا أراد أحدكم أن يأمر بالمعروف أو ينهى عن المنكر فليوطن نفسه على الصبر على الأذى ، ويثق بالثواب من الله تعالى ، فإن من يثق بالثواب من الله عز وجل لم يضره مس من الأذى " . إن الآمر بالمعروف و الناهي عن المنكر رجل نصب نفسه لبيان الحق ، والحق لا يرضي كل الناس ، لذا فإنه يتعرض للأذى ممن لا يرضيهم الحق فيكون ذلك ابتلاء له وامتحانا

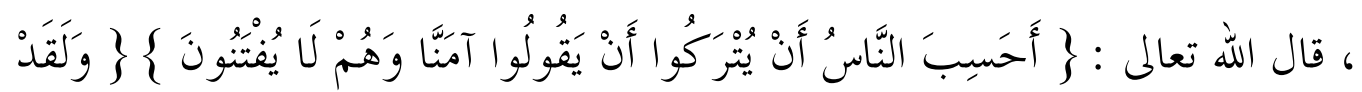

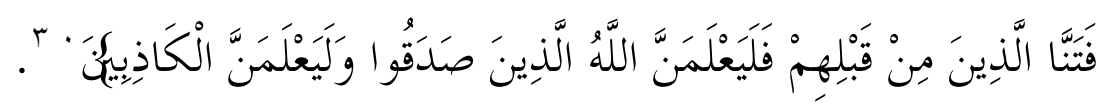

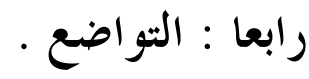

التواضع من أهم الصفات اللازمة لنجاح الداعية إلى الله الآمر بالمعروف و الناهي عن المنكر ، ويعني التواضع معرفة المرء قدر نفسه وبتحب الكبر ، و يتطلب أن يتجنب الإنسان المباهاة .بما فيه من الفضائل والمفاخرة بالجحاه والمال . . . . وأن يتحرز من الإعجاب و الكبر · و التواضع لا يكون إلا في أكابر الناس ورؤسائهم و أهل الفضل و العلم ، أما الإنسان العادي فلا يقال له : تواضع ، وإنما يقال له : " أعرف نفسك لا تضعها في غير موضعها " . و من التو اضع أن يتو اضع المرء مع أقرانهله ، و كثيرا ما تثور بين الأقران والأنداد روح المنافسة والتحاسد ، ور.ما استعلي الإنسان على قرينه ، ور.ما فرح بالنيل منه ،

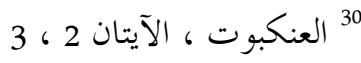
31 سلمان بن فهد العودة ، من أخلاق الداعية ( الرياض ) ، دار الوطن للنشر 1411 هـ ، ، ص 9 - ص 37 ، 37 
والحط من قدره وشأنه ، وعيبه بما ليس فيه أو تضخيم ما فيه ، وقد يظهر ذلك مثظهر

النصيحة والتقويم وإبداء الملاحظات ، ولو سمى الأمور بأسمائها الحقيقية لقال الغيرة . ومن التواضع أيضا التواضع مع من هو دونك ، فإذا وجدت أحدا أصغر منك ونك

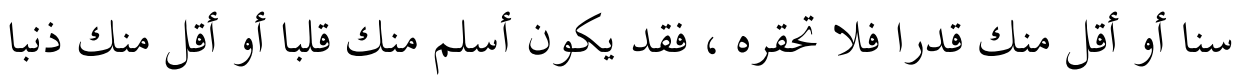
أو أعظم منك إلى الله قربا ـ حتى لو رأيت إنسانا فاسقا وأنت يظهر عليك سلك

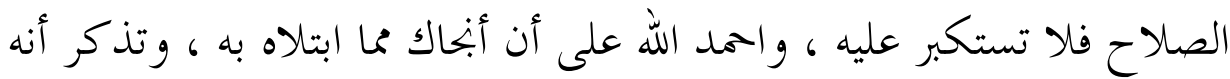
ربما يكون في عملك الصالح رياء أو عجب يهبطه ، وقد يكون عند هذا المذنب من الندم والانكسار والحوف من خطيئه ما يكون سببا في غفر ان ذنبه.

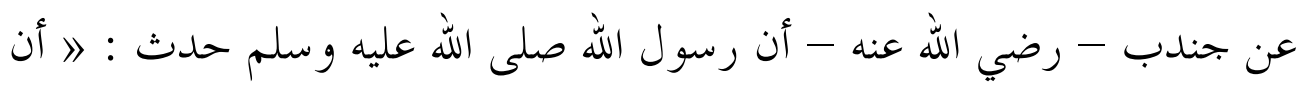

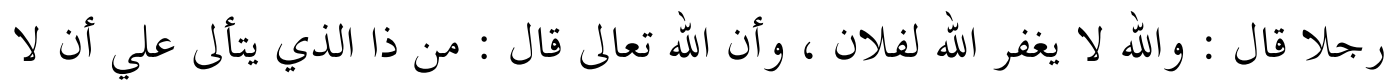
أغفر لفلان ؟ فإني قد غفرت لفلان وأحبطت عملك ه" ، أو كما قال . ومن التواضع ألا يعظم في عينك عملك ، إن عملت خيرا أو تقربت إلى الله

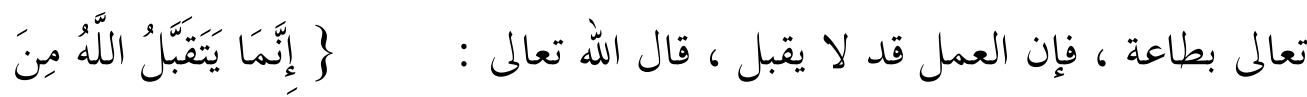
الْمُتَِّينَ

\section{خامسا: التحقق والتثبت من المنكز: - (التب}

من الأمور اللازمة لنجاح الدعوة إلى الله عز وجل ، التحقق والتثبت من المنكر المطلوب إزالته وتغييره ـ وقد تحدثنا عن الشق الأول من هذا الموضوع في فصل القواعد

$$
\begin{aligned}
& 32 \text { رو اه مسلم ، كتاب } 45 \text { ، باب } 39 \text { حديث } \\
& \text { 33 } 27 \text { سورة المائدة ، الآية }
\end{aligned}
$$


والمبادئ العامة التي تحكم القيام بفريضة الأمر بالمعروف والنهي عن المنكر ( تحت عنوان العلم ) ، وأنه لا بد للآمر بالمعروف والناهي عن المنكر أن يعرف حقيقة ما يأمر به وحقيقة ما ينهى عنه من وجهة النظر الشرعية ـ الحلم:

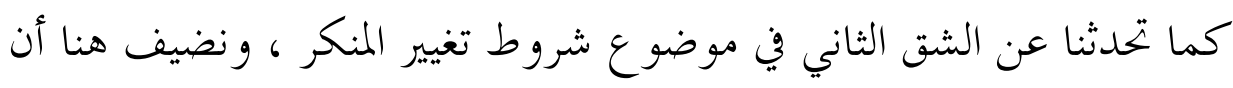

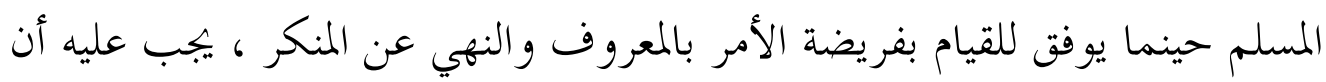

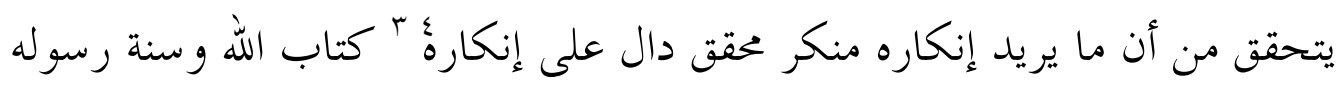

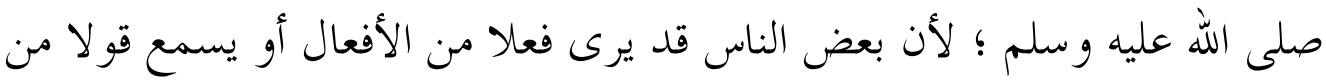

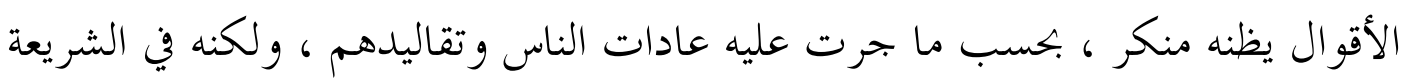
الإسلامية ليس بمنكر ، بل معروف وقد يحصل العكس ، فيرى بعض الناس المعروف

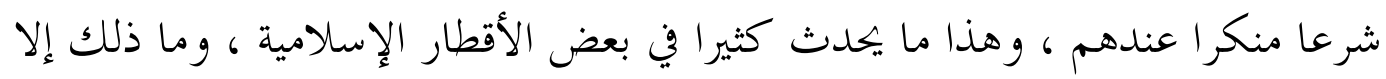
لأن الجها قد ضرب أطنابه على أبناء الأمة الإسلامية ، والتثبت من المنكر يتطلب أن كل من أراد أن ينكر منكرا - و كلنا مطالبون بذلك - فعليه أن يتأكد أن هذا المنكر وقع بالفعل ، ويجب عليه أن لا يسارع بنهي شخص معين أو جماعة معينة بمجرد الظن من غير تثبت أو بينة ، وأن الإنسان تكتنفه نوازع الحير ونوازع الشر ، وربما فكر في عمل المنكر ولكنه تراجع عنه و التحقق والتثبت من المنكر ، يتطلب من الآمر بالمعروف والناهي عن المنكر أنه عندما يبلغ بوجود منكر ما من شخص فإن عليه أن يتحقق من الهدف الحقيقي لذلك

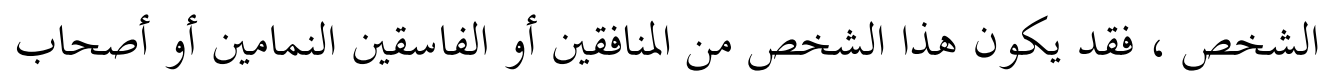
الغيبة الذين يفسدون في الأرض ولا يصلحون ، المخبرون من هذه الفئة قد لا يكون 34 عبده غالب أحمد عيسى ، أضواء على الأمر بالمعروف والنهي عن المنكر ، بيروت ، دار ابن زيدون ،

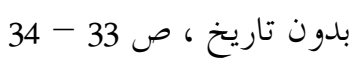


هدفهم العمل على إزالة المنكر وتغييره ، و وإنما يكون هدفهم الإيقاع وتشويه سمعة من

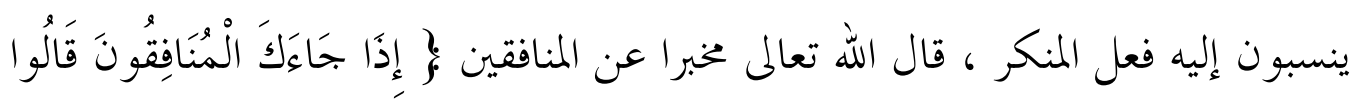

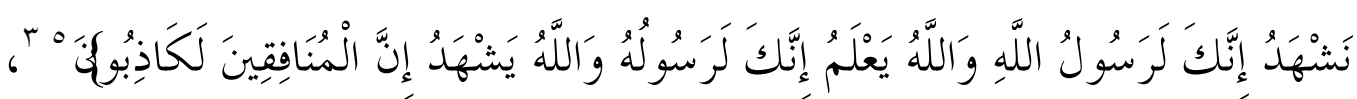

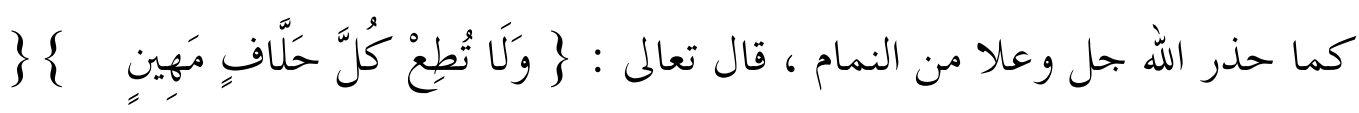

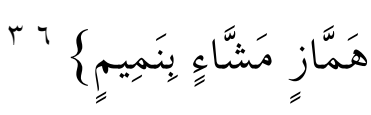

\section{سادسا: القدوة فيما يدعو إليه واجتناب ما ينهى عنلة}

من الأمور اللازمة لنجاح الدعوة إلى الله عز وجل أن يفعل ما يأمر به ويجتنب ما لهابل ينهى عنه ، وسبق أن أوضحنا في موضوع شروط الأمر بالمعروف والنهي عن المنكر أن

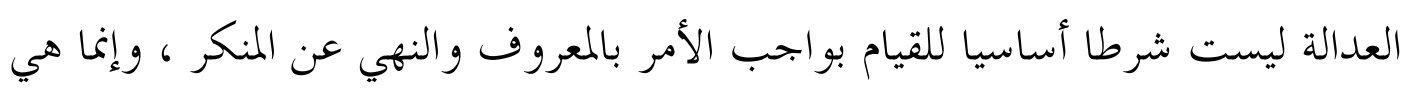

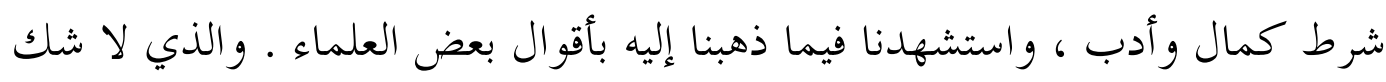

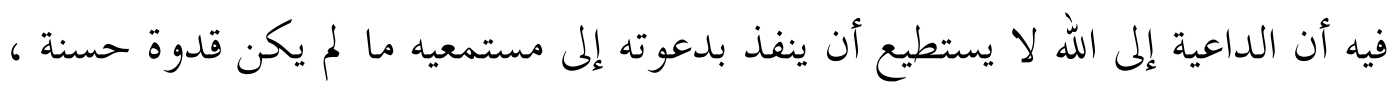

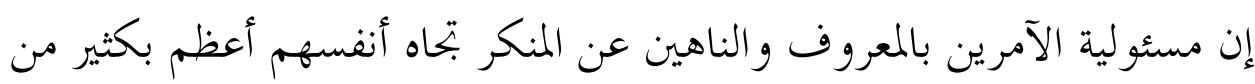

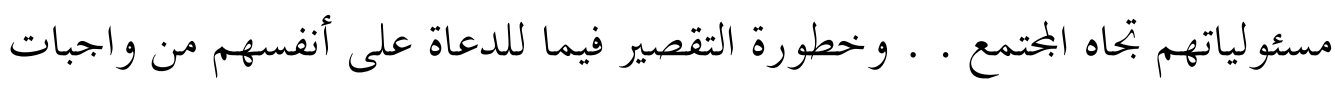
يفوق خطورة التقصير فيما للمجتمع عليهم من حقوق . . . فالدعاة إلى الله ينبغي أن يكونوا قدوة حسنة للمجتمع الذي يعيشون فيه ، تبدو في حياتهم آثار الرسالة التي يدعون إليهانه وقد أنكر الله - جل وعلا - على أولئك الذين يعظون الناس ولا يتعظون ،

$$
\begin{aligned}
& 35
\end{aligned}
$$

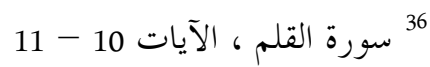

$$
\begin{aligned}
& 37 \text { فتحي يكن ، مشكلات الدعوة و الداعية ، بيروت ، مؤسسة الرسالة ، ص } 66 \text { - ص } 70
\end{aligned}
$$




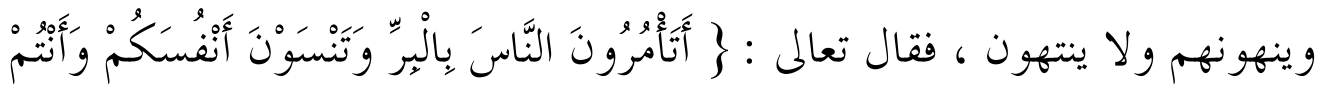

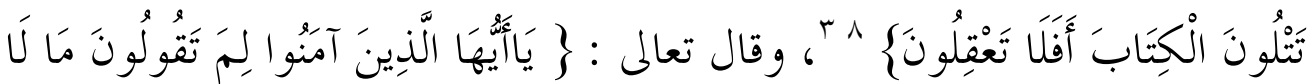

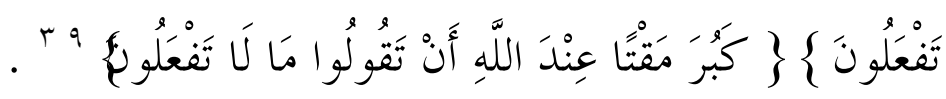
ن على الدعاة أن يتزموا خطى الدعوة في كل شأن من شئونهم في أقوالهم وأفعالهم في حياتهم الخاصة والعامة . . . في أنفسهم كأفراد ، وفي بيوتهم كأزواج

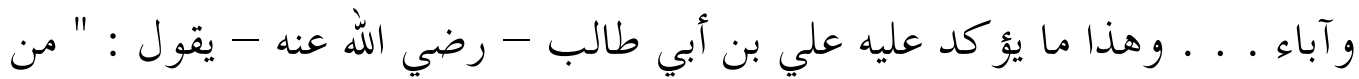
نصب نفسه للناس إماما فليبدأ بتعليم نفسه قبل تعليم غيره ، وليكن تهذيبه لسيرته قبل

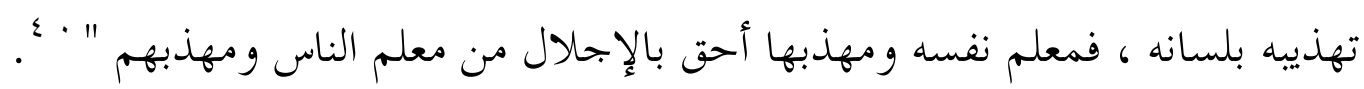
وهل يجين الذين يقولون ما لا يفعلون ـ . . و ويعظون و لا يتعظون ويرشدون ولا يسترشدون إلا سخرية العباد وسخط رب العباد ، يخسرون دينهم ودنياهم وذلك هو الخسر ان المبين ـ قال الشعب : " يطلع يوم القيامة قوم من أهل الجنة على قوم من أهل

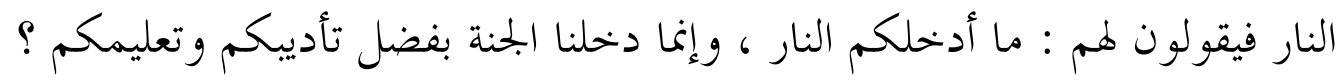
فيقولون : إنا كنا نأمر بالخير ولا نفعله وننهى عن الشر و نفعله " .

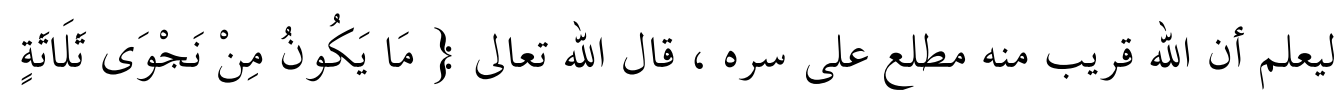

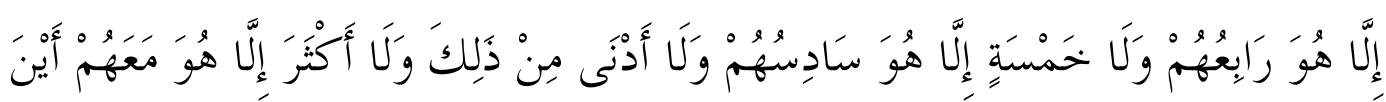

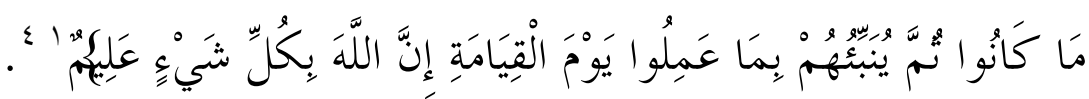

$$
\begin{aligned}
& \text { 38 - مسورة البقرة ، الآية } 44 \\
& 39 \text { سورة الصف ، الآيتان } 2 \text { - } 3 \\
& 40 \text { فتحي يكن ، مشكلات الدعوة والداعية ، بيروت ، مؤسسة الرسالة ، ص } 69 \text { ، } 69
\end{aligned}
$$

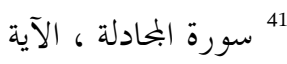




\section{خاتمة}

الدعوة الي الله هي الجهاد الدائم المفروض على المسلم ، وهو أصل مهم من أصول

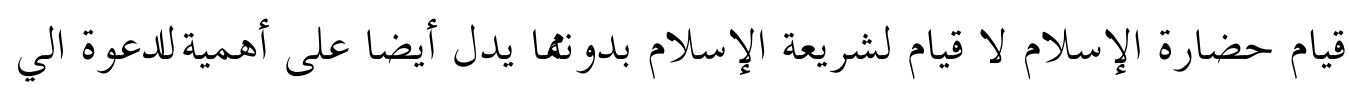
الله ما بينه رسول الله صلى الله عليه وسلم من أن الأمر بالمعروف والنهي عن المنكر

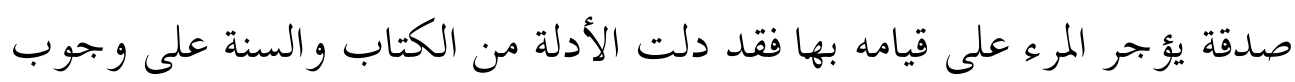

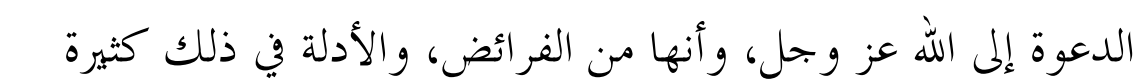

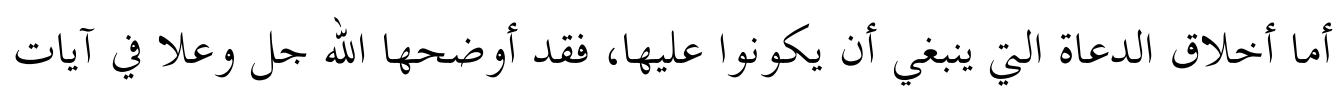
كثيرة، في أماكن متعددة من كتابه الكريم منها: أولاً: الإخلاص: فيجب على الداعية أن يكون مخلصا لله عز وجل، لا لا يريد رئاء

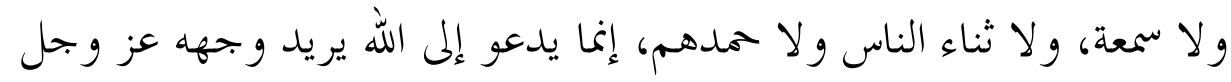

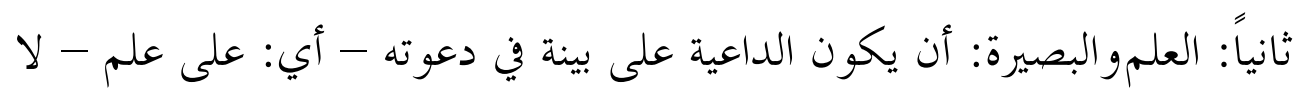
تكن جاهلا بما تدعو إليه

ثالثا : الصبر :الصبر من الصفات اللازمة لنجاح الدعوة إلى الله عز وجل ، وهو

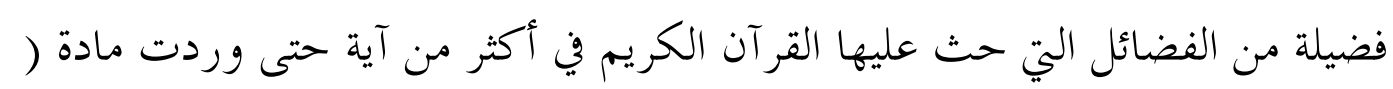

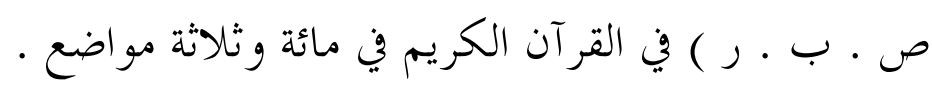

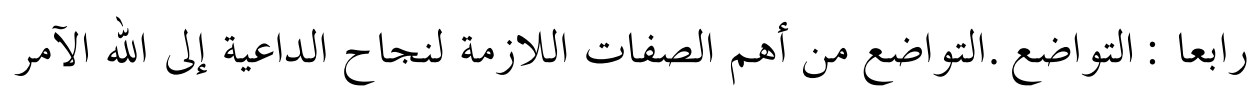
بالمعروف و الناهي عن المنكر ، ويعني التواضع معرفة المرء قدر نفسه وبتجب الكبر ،

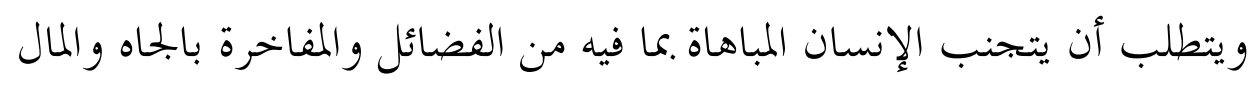

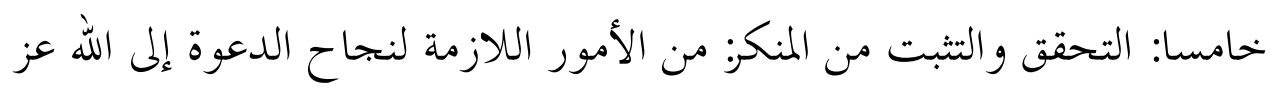
وجل ، التحقق والتثبت من المنكر المطلوب إزالته وتغييره 
سادسا: القدوة فيما يدعو إليه واجتناب ما ينهى عنه :من الأمور اللازمة لنجاح

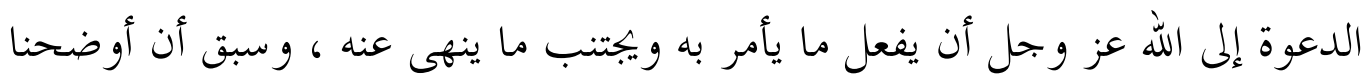
في موضوع شروط الأمر بالمعروف والنهي عن المنكر أن العدالة ليست شرطا أساسيا للقيام بو اجب الأمر بالمعروف والنهي عن المنكر ، وإنما هي شرط كمال وأدب ، واستشهدنا فيما ذهبنا إليه بأقوال بعض العلماء

\section{المصادر والمراجع}

ابن تيمية ، الأمر بالمعروف و النهي عن المنكر ، تحقيق محمد السيد الجليند ، جدة ، دار

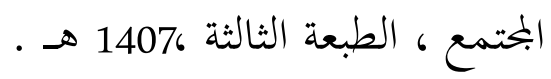

ابن تيمية ، الحسبة في الإسلامية ، القاهرة ، المطبعة الحسينية .

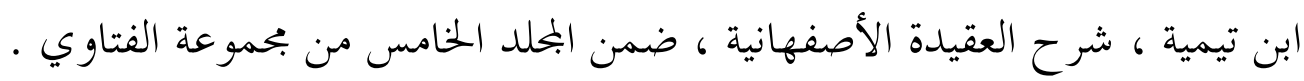

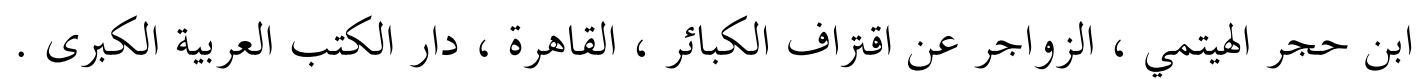

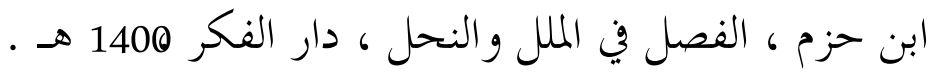

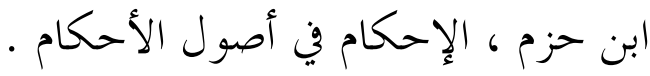

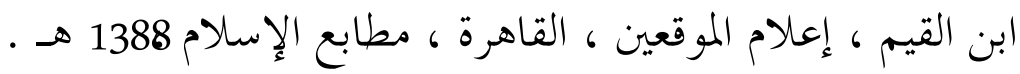

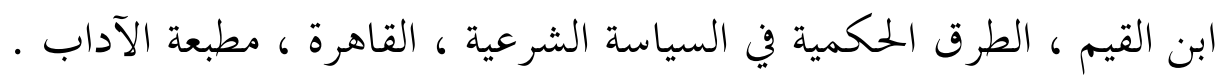
ابن كثير ، تفسير القر آن العظيم ، مطبعة البابي .مصر .

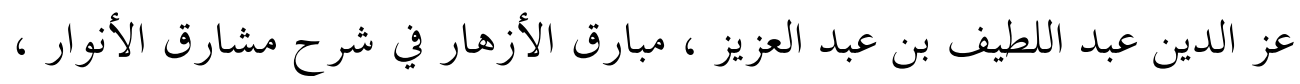

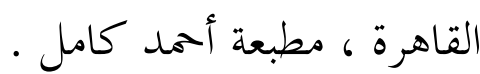

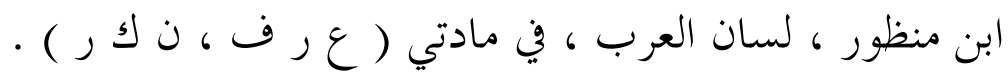

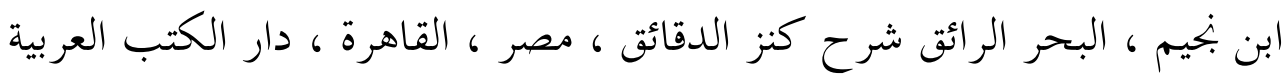

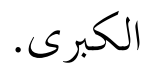


أبو بكر الجصاص ، أحكام القرآن ، القاهرة ، المطبعة البهية .

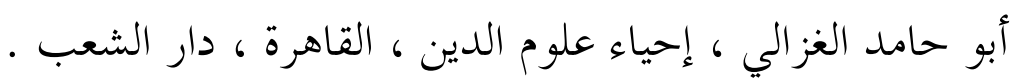

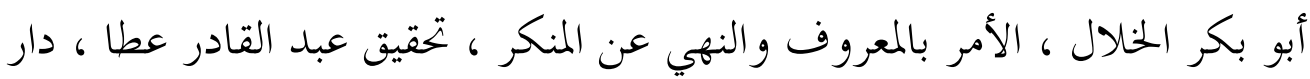

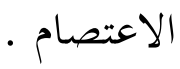

أبو السعود ، إرشاد العقل السليم إلى مزايا الكتاب الكريم ·

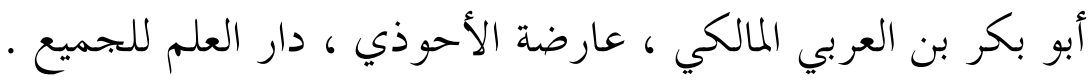

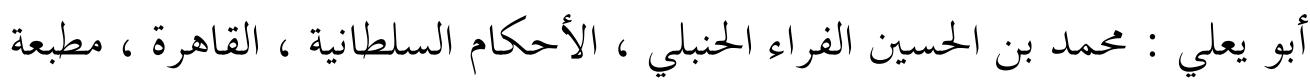

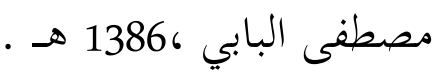

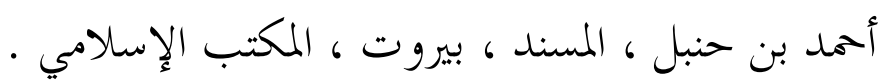

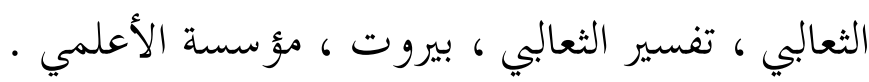
الحافظ بن رجب ، الفرق بين النصيحة والتعيير ، عمان ، دار عمر 1406هـ . الرازي ، مفاتيح الغيب ، القاهرة ، المطبعة الشرقية .

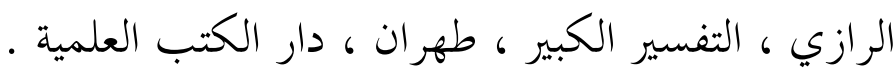

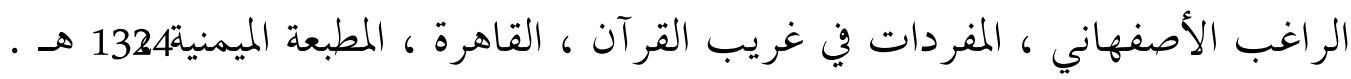
رشاد عباس معتوق ، نظام الحسبة في العراق ، جدة ، تهامة 1400 هـ . الزمخشري ، الكشاف عن حقائق التنزيل ، بيروت ، دار المعرفة .

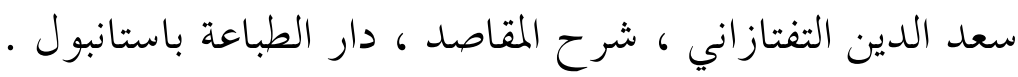

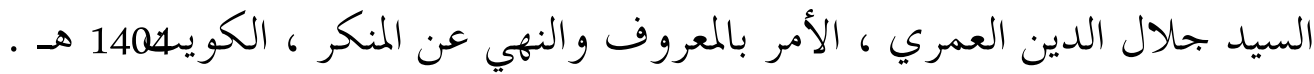

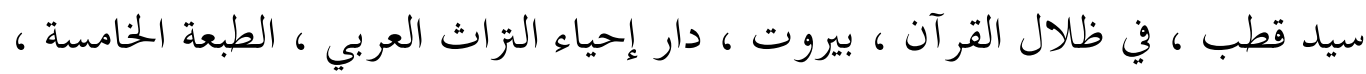
. 1386

سلمان بن فهد العودة ، من أخلاق الداعية ( الرياض ) ، دار الوطن للنشر141 هـ .

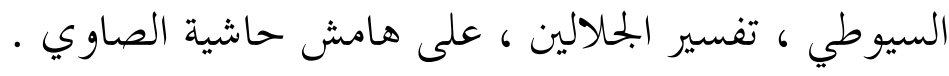


الشاطبي ، المو افقات في أصول الشريعة ، تحقيق وتعليق الشيخ عبد الله داراز ، القاهرة ،

$$
\text { المطبعة الرحمانية . }
$$

الشو كاني ، فتح القدير ، القاهرة .

الصنعاني ، سبل السلام ، شرح بلوغ المرام • الطبري ، تفسير الطبري القاهرة ، دار المعارف .

عبد الرحمن بن نصر الشيرازي ، نهاية الرتبة في طلب الحسبة ، بيروت ، دار الثقافة ، تحقيق السيد الباز العريني 1401 هـ .

عبد العزيز بن عبد الله بن باز ، الدعوة إلى الله وما ينبغي أن يتحلى به الداعية ، الكويت ، الدار السلفية 14046هـ .

عبد العزيز عبد الستار ، الأمر بالمعروف و النهي عن المنكر ، بيروت ، المكتب الإسلامي - عبد القادر عودة ، التشريع الجنائي الإسلامي ، ج1 بيروت ، دار الكتاب العربي . عز الدين بن عبد السالام ، قواعد الأحكام في مصالح الآنام ، القاهرة ، دار النشر لمباعة ، 1388 هـ 138

عمر رضا كحالة ، مباحث اجتماعية في عالمي العرب والإسلام ، دمشق ، مطبعة الحجاز ، 1394 هـ 139

عبد الله غالب أحمد عيسى ، الأمر بالمعروف والنهي عن المنكر ، بيروت ، دار ابن زيدون

عبد الله ناصح علوان تربية الأولاد في الإسلام ، جدة ، دار حافظ للطباعة والنشر ، . $\rightarrow 1410$

عبد الله بن حسن آل قعود ، أثر الأمر بالمعروف والنهي عن المنكر الرياض ، دار العاصمة .

فتحي يكن ، مشكالات الدعوة و الداعية ، بيروت ، مؤسسة الرسالة . 
فضل الهي ، الحسبة ، باكستان ، إدارة ترجمان الإسلام 1410 هـ . فضل الهي ، الحسبة في العصر النبوي وعصر الخلفاء الراشدين ، الطبعة الأولى ، باكستان ، إدارة ترجمان القر آن 1410 هـ ـ.

القرطي ، الجامع لأحكام القرآن ، القاهرة ، دار الكتاب العربي 1378 هـ . الكاشاني ، الصنائع في ترتيب الشرائع ، مطبعة شركة المطبوعات .مصر . الماوردي ، الأحكام السلطانية ، القاهرة ، مطبعة مصطفى البابي الحلبي13801هـ . محمود الألوسي ، روح المعاني ، بيروت ، دار إحياء التزاث العربي . محمد رشيد رضا ، تفسير القرآن الحكيم ، دار المنار بمصر 1365 هـ . محمد بن صالح العثيمين ، زاد الداعية إلى الله عز وجل ، الرياض ، مطابع المدينة ، . 1409

محمد أبو فارس ، الأمر بالمعروف و النهي عن المنكر ، عمان ، دار الفرقان ، الطبعة

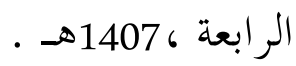

محمد بن علان الصديقي ، دليل الفالحين بطرق رياض الصالحين ، القاهرة ، مطبعة مصطفى البابي الحلبي1385 هـ .

محمد محمود الصواف ، الدعوة والدعاة ، القاهرة ، دار الاعتصام . محمد نعيم ياسين ، الجهاد ، ميادينه وأساليبه ، بيروت ، مؤسسة الرسالة1406 هـ . . محمد فاروق النبهان ، أبحاث إسلامية ، بيروت ، مؤسسة الرسالة 1406 هـ . ملا علي القاري ، المبين المعين لفهم الأربعين ، القاهرة ، المطبعة الجمالية . النووي ، شرح صحيح مسلم ، بيروت ، دار الفكر 1401 هـ . 